\title{
コストおよびエネルギー消費量による 一般廃棄物広域化シナリオの比較に関する研究
}

\author{
羽原 浩史 ${ }^{1}$ 松藤 $\quad$ 敏彦 $^{2} \cdot$ 田中 $\quad$ 信壽 ${ }^{3} \cdot$ 井上 真智子 ${ }^{4}$ \\ ${ }^{1}$ 正会員 北海道大学大学院工学研究科博士後期課程 ( ( 060-8628 札幌市北区北 13 条西8丁目) \\ ${ }^{2}$ 正会員 工博 北海道大学大学院助教授 工学研究科環境資源工学専攻廃棄物処分工学分野(同上) \\ ${ }^{3}$ 正会員 工博 北海道大学大学院教授 工学研究科環境資源工学専攻廃棄物処分工学分野 (同上) \\ 非会員 工修 （株）東京設計事務所（テ100-0013 東京都千代田区霞が関3-7-4）
}

\begin{abstract}
本研究ではまず広域化の制約条件となる収集輸送条件を検討した．次に広域化を想定した場合の中心都 市や周辺自治体の人口規模，中心都市から周辺自治体までの距離を定めた広域モデルを設定し，現在考元 られる主なごみ処理シナリオについて，LCA的な観点から広域化によるコスト，エネルギー消費量の変化 を計算した．これらによって，広域処理によるコスト（コストの内訳を含む），エネルギ一消費量を比較 検討し，リサイクル型のごみ処理シナリオが成立する条件を検討した. 最後に標準広域モデルのパラメー 夕感度分析を行った。
\end{abstract}

Key Words : Regional solid waste management system, waste collection and transport, cost and energy consumption

\section{1. はじめに}

平成 9 年 1 月「ごみ処理に係るダイオキシン類発生防 止等ガイドライン」の制定に続いて, 1公共事業の費用 削減，(2)リサイクルの推進，(3)余熱利用の推進と地球温 暖化防止, (4)ダイオキシン類の効率的な削減等の課題に 対応するため, 平成 9 年 5 月厚生省（当時）は「ごみ処 理の広域化計画について」を都道府県に通知した").こ のため, 各都道府県で注従来の自区内処理から経済的, 効率的な処理への転換の検討をはじめ, 概ね10〜20年後 を目標年次とした広域化計画を策定している. しかし， 策定された広域化計画は今後の施設整備（更新, 統合, 廃止）の具体的計画を示したものから，広域化の圈域を 決めただけのものまであり, 全体として十分なものと なっていない2).

さらに，平成13年 5 月には環境省より「廃充物の減 量その他その適正な処理に関する施策の総合的かつ計画 的な推進を図るための基本的な指針」が発表され，広域 化を前提として, 焼却中心の処理方法からさまざまなり サイクルを行う処理方法を検討し, 地域における最適な 処理シナリオを選択するよう要請されている2).

ごみ処理の広域化に関する研究としては, 焼却処理 の広域化をエネルギ一消費量, $\mathrm{CO}_{2}, \mathrm{NO}_{\mathrm{x}}, \mathrm{SO}_{\mathrm{x}}$ 排出量, あるいはコストで評価した仁井本ら ”, 中野ら")の研究， ブロック割方法の比較をエネルギー消費量, $\mathrm{CO}_{2}$, ある
いはダイオキシン類, ばいじん発生量, コストなどで比 較した谷口ら5, 清水ら ${ }^{6)}$ の研究があり, いずれも対象 地域の範囲を固定し, 処理方法も一定としている. しか し広域化に関してコスト, 資源保全や環境影響を考慮し て，処理施設の設置方法（処理処分施設を 1 箇所に集約 するか，一部を分散するか等），広域化が可能となる収 集輸送の条件，広域化の適正規模，広域化によるメリッ トとデメリット, また処理シナリオの選択方法などに関 する一般性のある研究は行われていない.

本研究では, まず広域化によってコストやエネルギー 消費量の增大が㲘念される収集輸送について, 必要収集 車両台数を検討し, ごみ量, 輸送距離をパラメータとし て施設までの直接輸送と中継輸送を比較した. 次に, 広 域化を想定した場合の中心都市や周辺自治体の人口規模, 中心都市から周辺自治体までの距離をモデル化して, 現 在考えられる主なごみ処理シナリオについて, LCA的 な観点からコスト, エネルギー消費量を計算し, 処理シ ナリオの比較およびリサイクル型処理シナリオの実施可 能性を検討した. 最後にモデル化した中心都市や周辺自 治体の人口規模, 中心都市から周辺自治体までの距離に ついては，それらの影響について感度分析を行った。 


\section{2. 処理シナリオとこみ処理量の設定}

\section{(1)処理シナリオ}

本研究では, 処理シナリオを表一 1 のように設定する 処理方法としては, 焼却, 埋立, 堆肥化, RDF（ごみ 燃料）化を考え，可燃ごみをさらに厨芥とそれ以外の可 燃物に分けて堆肥化と焼却, 堆肥化とRDF化を行う ケースも考える. RDF化の場合，製造されたRDFに よって発電を行うとする. 表-1には，各シナリオにお けるごみの分別方法（不燃・粗大ごみ等）とおのおのご みがどのように処理されるかを示している. なお，資源 ごみの資源選別処理，粗大ごみの破砕選別処理は各シナ リオに共通して実施する.

広域化を考えるとき，処理施設を 1 都市に設置して 周辺自治体のごみを集中処理するシナリオが考えられる

(以下では，集中処理する施設を設置する都市を広域化 の中心都市という意味で「中心都市」と呼ぶ）。一方で すべてのごみ処理施設を中心都市に設置することは，負 担が集中し，住民合意を得にくいため，粗大ごみ処理施 設と埋立地を自治体個々に設置することも考えられる. 図ー 1 (a)(b)に焼却についての 2 つのシナリオを示す.

「焼却 $1 」$ はすべての自治体のごみを中心都市 1 箇所に 輸送して集中処理する（以下「集中処理シナリオ」と呼 ぶ）もので，広域化の最も単純な処理方法と考えられる。 一方「焼却 $2 」 は$ は焼却を 1 箇所で行うのは(a) と同じだ が，不燃・粗大ごみの処理とその残渣の埋め立てを個々 の自治体で行う（以下「個別埋立シナリオ」と呼ぶ）. なお，焼却残渣をそれぞれ持ち帰るケースもあり得るが， 効率性を考えて中心都市に埋め立てるとする．表一1で は, 各処理施設が 1 籄所か, 個別に設けるかを○および ○で示した.

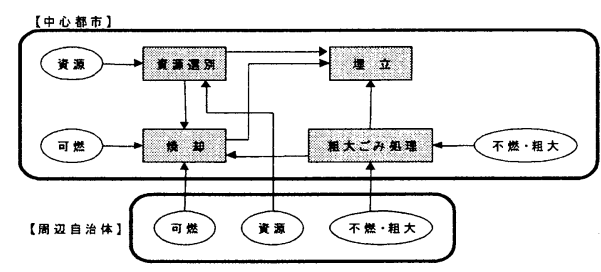

（a）「憤却1」シナリオ

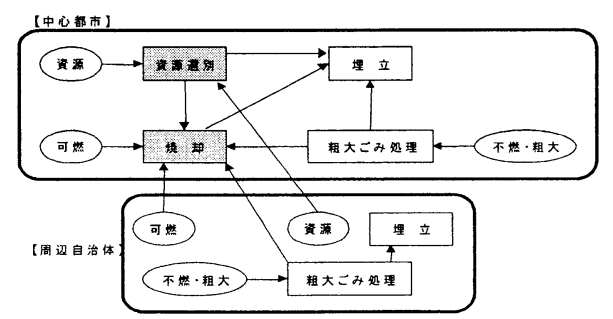

（b）「焼却2」シナリオ（粗大ごみ処理，埋立を個々の自治体で行う） 表-1＼cjkstart本研究で検討対象とした処理シナリオと各処理の 対象ごみ

\begin{tabular}{|c|c|c|c|c|c|c|c|c|c|c|c|}
\hline \multirow{3}{*}{ 处野施設 } & \multicolumn{11}{|c|}{ 处理ナオオ } \\
\hline & \multicolumn{2}{|c|}{ 焼 却 } & \multicolumn{2}{|c|}{ 埋立 } & \multicolumn{3}{|c|}{ 堆畞化 } & \multicolumn{2}{|c|}{$\begin{array}{c}\text { 㘯肥化 } \\
+ \\
+ \\
\text { 焼 却 }\end{array}$} & RDF化 & $\begin{array}{c}\text { 堆囝化 } \\
+ \\
\text { RDF化 }\end{array}$ \\
\hline & 1 & 2 & 1 & 2 & 1 & 2 & $1^{\prime}$ & 1 & 2 & 1 & 1 \\
\hline \multirow[b]{2}{*}{ 資皌選别施設 } & 0 & $\mathrm{O}$ & $\mathrm{O}$ & $\mathrm{O}$ & $\mathrm{O}$ & $\mathrm{O}$ & $\mathrm{O}$ & $\mathrm{O}$ & $\mathrm{O}$ & $0: 0$ & $0 \quad 0$ \\
\hline & \multicolumn{2}{|c|}{ 資缷原 } & \multicolumn{2}{|c|}{ 資原 } & \multicolumn{3}{|c|}{ 資嫄 } & \multicolumn{2}{|c|}{ 資㟲 } & 資源 & 資原 \\
\hline \multirow{2}{*}{ 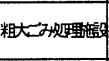 } & 0 & 0 & 0 & - & 0 & 0 & 0 & 0 & 0 & \begin{tabular}{l|l|}
0 & 0 \\
\end{tabular} & 00 \\
\hline & \multicolumn{2}{|c|}{ 不然粗大 } & \multicolumn{2}{|c|}{ 粗大 } & \multicolumn{3}{|c|}{ 粗大 } & \multicolumn{2}{|c|}{ 不然粗大 } & 不然粗大 & 不然粗大 \\
\hline \multirow{2}{*}{ 堆肥化施㪣 } & -1 & $\cdot$ & -1 & - & $\mathrm{O}$ & 0 & 0 & 0 & $\mathrm{O}$ & \begin{tabular}{l|l|}
- & - \\
\end{tabular} & 00 \\
\hline & - & & \multicolumn{2}{|l|}{-} & \multicolumn{3}{|c|}{ 屋芥 } & \multicolumn{2}{|c|}{ 剭芥 } & - & 厨芥 \\
\hline \multirow{2}{*}{ RDF化施都 } & - & - & - & - & - & -1 & - & & & \begin{tabular}{l|l|}
0 & 0 \\
\end{tabular} & \begin{tabular}{l|l}
0 & 0
\end{tabular} \\
\hline & 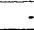 & & \multicolumn{2}{|l|}{ - } & \multicolumn{3}{|c|}{ - } & - & & 可然 & 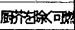 \\
\hline \multirow{2}{*}{ RDF発車施段 } & - & - & - & - & - & - & - & - & - & \begin{tabular}{l|l|}
0 & 0 \\
\end{tabular} & 00 \\
\hline & & & & \multicolumn{3}{|c|}{ - } & - & & ROF & FDF \\
\hline \multirow{2}{*}{ 燅却施殷 } & 0 & 0 & - & - & - & - & - & 0 & 0 & \begin{tabular}{l|l}
- & - \\
\end{tabular} & \\
\hline & \multicolumn{2}{|c|}{ 可竳 } & - & & \multicolumn{3}{|c|}{ - } & \multicolumn{2}{|c|}{ 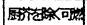 } & - & - \\
\hline & 0 & & 0 & & $\mathrm{O}$ & 0 & $\mathrm{O}$ & 0 & 0 & \begin{tabular}{ll|}
0 & 0
\end{tabular} & 00 \\
\hline & 残查 & 万小 & 可蜘 & 不然 & 屋劳学 & 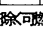 & E不轮 & 残直 & बम & 残查のみ & 残查のみ \\
\hline
\end{tabular}

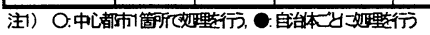

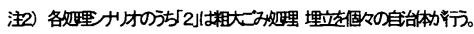

埋立，堆肥化，RDF化の場合にも，それぞれ「1」

「2」のシナリオを考える．ただしRDF化はRDF製造 を各自治体が個別に行い，RDFを 1 箇所に集めて発電 するシナリオを「RDF化 $1 」$ とする. 堆肥化について は, 人口規模の小さい自治体からの厨芥排出量は少ない ため集中処理が望ましいが, 生産される堆肥の需要先は (1)使いやすさ（夾雑物がない，悪臭がない等），(2)有効 性と安全性, (3)適正価格での安定供給の面”)から現状で は限定されるため, 製品堆肥の販売・使用は厨芥発生自 治体の責務と考えて, 個々の自治体に堆肥化施設を設置 する「堆肥化 1'」シナリオも考える. 図一 1 (c)「(堆 肥化 $+R D F$ 化) $1 」$ は, リサイクルを徹底推進した事例 として堆肥化とRDF化を行うシナリオを示す.

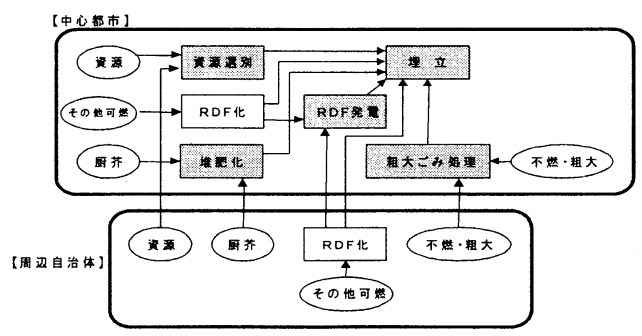

（c）「(堆肥化 + RDF化）1」シナリオ

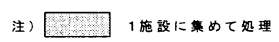

図-1＼cjkstart処理シナリオとごみ流れの例 


\section{(2)こみ処理}

各収集ごみ種ごとの組成別年間ごみ量を人口 1 万人 当たりとして表ー2のように設定した.

筆者らは自治体が行うごみ処理評価プログラムを作成 し8), 9)，ホームページでも公開しており, 表一2の数 值はそこで用いたものである. またこの数值は容器包 装リサイクル法(通称) 実施後を想定しているが, 家電 リサイクル法(通称)実施後の影響は考慮していない.

表ー 1 に示した処理シナリオごとに異なった分別を するので，収集区分ごとのごみ量を以下のように与え た. 表一 3 に堆肥化, RDF化の例を示す. 堆肥化の場 合は可燃ごみの中から剭芥が分別され, 焼却処理を行 わないので残りの可燃ごみと不燃ごみを埋め立てる

（表一 1 参照）。事業系ごみは一部の嶎芥を堆肥化原 料とし, 残りは埋め立てる. RDF化の場合は, 資源ご み, $\mathrm{RDF}$ 化ごみ以外は埋め立てる. なお表一 2 , 表一 3のごみ量, および家庭系ごみに対する事業系ごみの 割合は札幌市の実績に基づいており，自治体によらず 一定として計算する.

\section{3. 収集輸送の検討}

\section{（1）収集車両による収集可能人口と輸送距離の計算方法}

広域化の実施においては, 輸送距離が主要な検討因 子である．船や鉄道を使用するならば範囲を広げること ができるが，ここでは一般的な車両による収集輸送を考 える. 例として可燃ごみを週 2 回の頻度で収集した場合 の, 収集可能なごみ量に対する人口と処理施設までの距 離の関係を計算する.

収集車両1台が 1 日に入回の作業（1回の収集を「ト リップ」と呼ぶ) で収集可能な人口は, 次式で計算され る. 仮定した数值を共に示す（表- 2 と同様に以前作成 したプログラムから引用した）。

$$
\mathrm{V}_{\mathrm{C}} \lambda \rho=4 / 3 \times \mathrm{q} \times \mathrm{P} / 365
$$

$\mathrm{V}_{\mathrm{C}}:$ 荷箱の容積 $\left[\mathrm{m}^{3}\right]=8$

$\mathrm{q}:$ 可燃ごみ発生量 $[\mathrm{t} /($ 人·年 $)]=0.186$

P ：1トリップで収集可能な人口[人]

$\rho:$ ごみのかさ密度 $\left[\mathrm{t} / \mathrm{m}^{3}\right]=0.36$

式(1)右辺の $4 / 3$ は, 週 6 日収集のとき収集区域を 3 分割 し, 1 日で収集輸送すべき地域は全体の $1 / 3$ となり, 最 大 4 日分のごみを収集するためである，収集作業時間は 以下のように計算できる.

i ) 積み込み・積みおろし時間 [h/日]

$$
\mathrm{t}_{2}=0.18 \mathrm{~V}_{\mathrm{C}} \lambda \rho+0.08 \lambda
$$

$0.18:$ ごみを積み込むのに必要な時間 $[\mathrm{h} / \mathrm{t}]$ 0.08 : 処理処分施設内の計量・積みおろし時間 $[\mathrm{h} /$ 回 $]$ ii)ステーション間の移動時間[h/日]

$$
\mathrm{t}_{3}=\left(100 \times 10^{-3}\right) \times\left(\mathrm{n}_{\mathrm{S}}-1\right) / \mathrm{s}_{\mathrm{m}}
$$

\begin{tabular}{|c|c|c|c|c|c|c|}
\hline \multirow{3}{*}{ ごみ組成 } & \multicolumn{6}{|c|}{ [ $t /$ 年 $]$} \\
\hline & \multicolumn{4}{|c|}{ 家庭系ごみ } & \multicolumn{2}{|c|}{ 事業系ごみ } \\
\hline & 資源ごみ & 可燃ごみ & 不燃デみ & 粗大ごみ & 焼趣に゙み & 埋立ごみ \\
\hline 厨芥 & 0 & 844 & 92 & 0 & 159 & 18 \\
\hline $\begin{array}{l}\text { 紙 } \\
\end{array}$ & 139 & 613 & 63 & 0 & 398 & 44 \\
\hline プスチック & 32 & 214 & 105 & 0 & 103 & 11 \\
\hline 金属 & 89 & 25 & 33 & 0 & 56 & 6 \\
\hline ガラス & 125 & 20 & 27 & 0 & 40 & 4 \\
\hline 布 & 0 & 128 & 28 & 0 & 40 & 4 \\
\hline 粗大物 & 0 & 17 & 13 & 100 & 0 & 0 \\
\hline 合計 & 386 & 1860 & 361 & 100 & 796 & 88 \\
\hline
\end{tabular}

表-2 収集形態別のごみ組成(人口1万人当たり)

\begin{tabular}{|c|c|c|c|c|c|}
\hline \multirow{2}{*}{\multicolumn{2}{|c|}{ ごみ種 }} & \multicolumn{3}{|c|}{ 各処理シナリ才時のごみ量[t/年 $]$} & \multirow{2}{*}{$\begin{array}{c}\text { 収集時か } \\
\text { さ密度 } \\
{\left[\mathrm{t} / \mathrm{m}^{3}\right]}\end{array}$} \\
\hline & & 「焼却」 & 「堆肥化] & 「RDF化」 & \\
\hline \multirow[t]{5}{*}{ 家庭系 } & 資源ごみ & 386 & $\leftarrow$ & $\leftarrow$ & 0.20 \\
\hline & 可燃ごみ & 1860 & $1860-793$ & $1860-1846$ & 0.36 \\
\hline & 不燃ごみ & 361 & $\leftarrow$ & $\leftarrow$ & 0.25 \\
\hline & 粗大ごみ & 215 & $\leftarrow$ & $\leftarrow$ & 0.17 \\
\hline & $\begin{array}{l}\text { 欴芥ごみ } \\
\mathrm{RDFこみみ}\end{array}$ & & 793 & & \\
\hline \multirow[t]{3}{*}{ 事業系 } & 焼却ごみ & 796 & $796-44$ & $796-138$ & 0.28 \\
\hline & 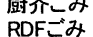 & & & 138 & \\
\hline & 埋立ごみ & 88 & $\leftarrow$ & $\leftarrow$ & 0.28 \\
\hline
\end{tabular}

表-3人口1万人当たりごみ処理量

注1)資源ごみはひん, 缶、PETホトトルを回収すると仮定

注2)「ヶ」は「焼却」と同じであることを示す。

$100:$ ステーション間距離 $[\mathrm{m}]$

$\mathrm{n}_{\mathrm{s}}$ : 収集ステーション数 $=(\mathrm{P} / 60) / 3 \quad$ （60人に 1 箇所）

$\mathrm{s}_{\mathrm{m}}:$ ステーション間の移動速度 $[\mathrm{km} / \mathrm{h}]=15$

iii)輸送のために残された時間[h/日]

$$
\mathrm{t}_{1}=\mathrm{t}_{\mathrm{d}}-\mathrm{t}_{2}-\mathrm{t}_{3}=2 \mathrm{~L} / \mathrm{s}_{\mathrm{H}} \times \lambda
$$

$\mathrm{L}$ :処理施設までの輸送距離 (最長輸送可能距離)

$\mathfrak{t}_{\mathrm{d}}: 1$ 日作業時間(休㮩, 洗車, 準備を除く) [h/(台·日) $]=5$ $\mathrm{s}_{\mathrm{H}}:$ 輸送速度 $[\mathrm{km} / \mathrm{h}]=40$

Lは，作業時間をちょうど使い切る輸送距離である.

\section{(2) 必要収集車両台数の計算例}

式(1) (4)で入 = 1，2 $\cdots$ として計算すると， 1 台が 1 日に収集可能な人口と輸送距離の関係が図ー2のプ ロット点のように求まる. 図中の太線は, 車両 1 台のと き, 所定作業時間ちょうどに作業を終了できる人口と輸 送距離の関係（式(1)〜(4)の解）を示している. 図中の (1)，(2はそれぞれ1トリップ，2トリップの作業を, 車 両が満載状態で所定時間に終了する条件にあり, 時間お よび収集車容量の使用効率が最大である. 図より輸送距 離が短くなれば最大 7 回の作業が可能である.太線より 右になるともう 1 台の収集䡃必要になる.

図一2の図中の「メ」印は, 参考として北海道帯広 市周辺自治体の人口と帯広市までの距離をプロットした ものである.ごみ量が少なく収集車 1 台にも満たない効 率の悪いケースについての計算を避けるため, 自治体配 
置のモデル化のときは最小人口を 1 万人とした. ただし 不燃ごみ, 粗大ごみはごみ量が少ないために可燃ごみと 較べて，1トリップに相当する人口が 4 〜 倍となる. すなわち 1 万人を最小自治体人口としても, 不燃ごみ, 粗大ごみ収集については, 効率の悪い条件で計算を行う ことになる.

\section{（3）直接銅送と中継脍送の比较検討}

家庭からの排出されたごみは, 収集車によってその まま直接処理施設へ搬入することが一般的である. しか し，図一2に示したように輸送距離が長くなると必要な 車両数が多くなって, 収集輸送の効率は急激に低下し, 中継施設を設けて大型の車両に積み替える中継輸送を行 う必要が生じる. 収集輸送コストがごみ処理全体に占め る割合は，20万人都市の周辺に 1 万人の自治体が 20 ある としたとき $50 \%$ 程度以上である（後述する図ー 7 の $\mathrm{RDF}$ 化を除く各処理シナリオの 2 段目参照）。した がってコストが制約となると考え，可燃ごみについて輸 送距離を変数とし, 直接輸送と中継輸送のコストを比較 した. なお計算条件は, 中継輸送車 (容量 $16 \mathrm{~m}^{3}$, 輸送速 度 $50 \mathrm{~km} / \mathrm{h}$, 購入費 10 百万円/台）, 収集車（購入費 5 百 万円/台，その他の条件は3. (1)参照) とする.

計算結果を図ー 3 に示す. 直接輸送の場合, 人口が 多いときは車両数も多いので輸送距離に対して収集輸送 コストは直線的に增加するが，人口が少ないときには車 両数が $1 \rightarrow 2 \rightarrow 3$ 台と変化するため階段状になる. 中継 輸送を行う場合は, 中継施設のコストがごみ量によって 大きくは変化せず, ごみ $1 \mathrm{t}$ 当たりの収集輸送コストは 主に中継輸送車両の台数に依存し, 積載量が大きいため 輸送距離に対してコストはなだらかに增加する.

図一3によると人口が少ないときを除き，概ね輸送 距離 $20 \mathrm{~km}$ 以上で中継輸送が有利となることがわかる. 以 降の計算においては各周辺自治体ごとに直接輸送と中継 輸送のコストを計算し，有利な方を採用することとした.

\section{4. コストおよぴエネルギー消筫量の計算方法}

\section{（1）計算に用いた近似式}

前述のように筆者らは自治体内の都市ごみ処理を評 価するプログラムを作成している. しかし, 広域化処理 の場合について計算を行うときには自治体間の輸送があ り，また一部のごみ種を各自治体で単独処理することも あるため，処理パターンは複雑になる，収集輸送は各自 治体ごとに計算しなければならないし，処理処分施設ご との計算が必要になる. 本研究で目的とするのは, 自治 体の地理的人口分布，広域化の範囲が，表一 1 に示す処 理シナリオを選択したときどのような影響を与えるのか, 各処理シナリオの適正な広域化規模あるいは限界はどの

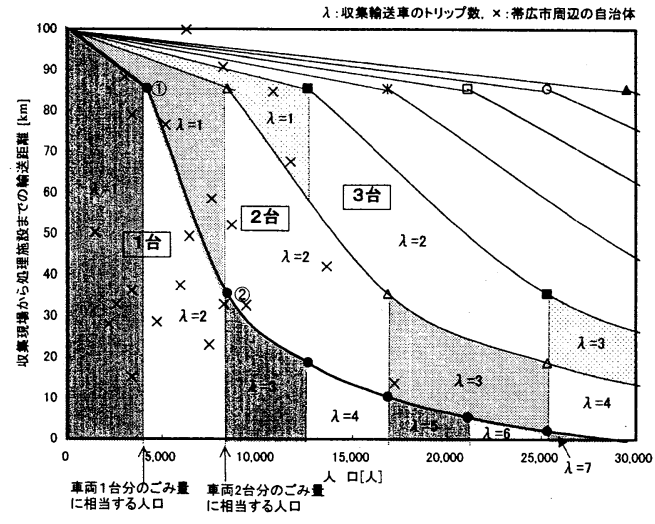

図-2 輸送距離と収集・輸送車両必要台数の関係(可燃 ごみ, 週2回収集の場合)

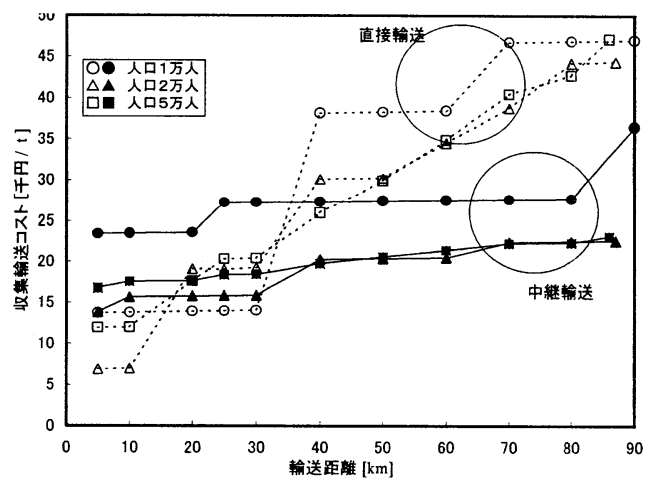

図-3処理施設までの輸送距離と収集輸送コストの関係 (可燃ごみ)

くらいかといった概略を知ることである，そのため，評 価プログラムを用いて人口，処理方法などの条件を変え て多数回の計算を行い，コストおよびエネルギー消費量 を計算する近似式を作成した.

収集輸送に関するコストおよびエネルギー消費量の 近似式は，焼却シナリオの下で人口，輸送距離を変えて 計算を繰り返して得た. 可燃ごみの場合のコストは図一 3に示されており,これを1次式で近似した. ごみ種に よってかさ密度が異なるが, 定数項の異なる式で近似す ることができた. 処理に関するコストおよびエネルギー 消費量は，ごみ量だけに依存するので表ー1の処理シナ リオに対して人口を変えて計算を行い，ごみ処理量に対

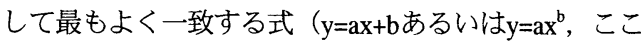
でy；コスト[百万円/年］またはエネルギー消費量 [Gcal/年], $\mathrm{x}$; ごみ処理量 $[\mathrm{t} /$ 年] $)$ を求めた. 式の記述 は省略するが，これを用いるとごみ処理量当たりのコス トおよびエネルギー消費量は図一 4 (a)(b)に示すように なる。 


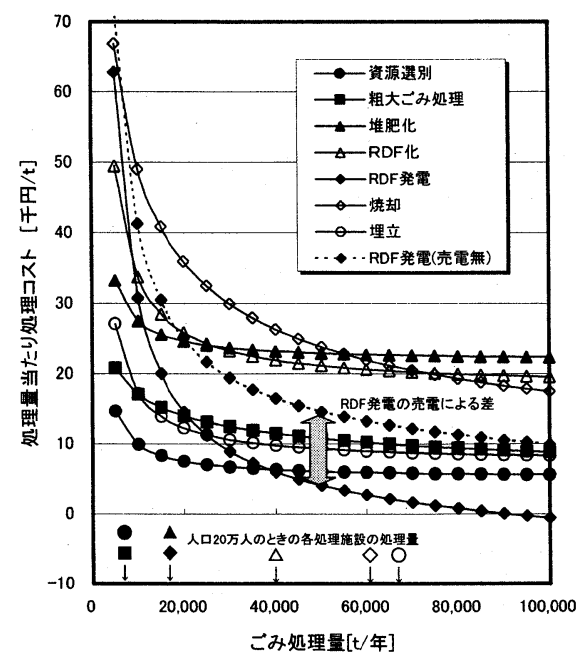

(a) コスト

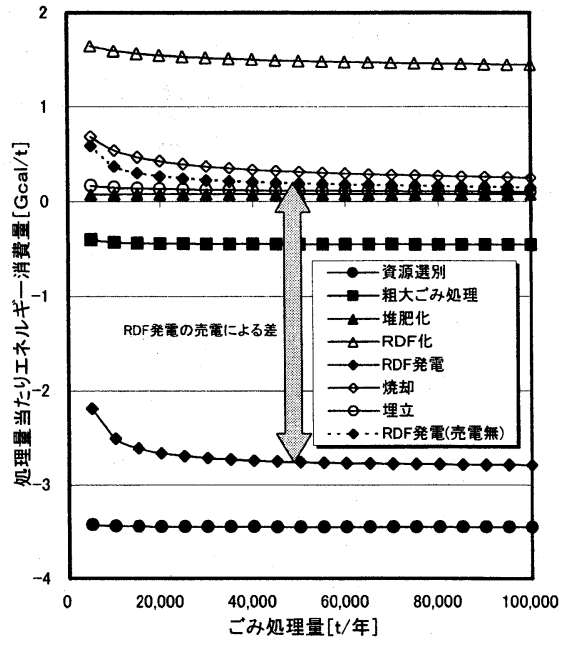

(b)エネルギー消費量

図-4 計算に用いた処理施設のコスト・エネルギ一消費量

\section{（2）処理施設の計算条件}

各処理には多くの施設設計条件があるが, 主なもの を挙げると以下のようになる.

・資源選別施設： スチール䂐, アルミ缶, びん, PETを回収

・焼却施設：スト一カ炉（2炉）, 燃焼ガス 冷却方式はボイラ式, 場内利用分 のみ発電, 集塺灭処理方式は溶融 固化（焼却灰を含む）

- 最終処分場：山間埋立地, 計画使用期間10年, 埋立区画は 2 区画

- 残 渣 処 理：RDF化残渣は全て埋立, それ以 外の残椬は焼却施設があるときに は焼却

- RDF発電施設：所内利用率 $17 \%$, 発電効率 $30 \%$, 売電単価 8 円 $/ \mathrm{kWh}$

また，コストには以下のものを含めている.

・土木建設費（国庫補助を含めない，耐用年数 20 年)

- 運転費 (人件費, 電力費, 燃料費, 水道費, 薬 品費, 整備補修費)

- 回収資源, 熱・電気等の売却利益

土木建設費は耐用年数で割り, 運転費, 売却利益 （負值）を加えてごみ処理量当たりのコストとした. 一 般廃棄物処理事業実態調查 (平成 7 年版) ${ }^{10}$ 上り算出し た全国平均の中間処理コストは約18千円/ t, 埋立コスト は約 7 千円/tであり，図ー4に示した各処理のコストは ほぼ一致している. エネルギ一消費量については, 電力, 燃料等の使用量, および回収資源量にエネルギ一原単位
をかけて算出した．施設建設に伴うエネルギー消費は厳 密には積み上げ法によるべきであるが，井村ら"1)の研究 を参考として土木建築・整備補修のエネルギ一原単位を 土木建築15.1Mcal/千円, 整備補修 $11.5 \mathrm{Mcal} /$ 千円とし, 工事費を乗じて求めた ${ }^{8)}$. RDF発電施設については, 文 献 ${ }^{12)}$ 参考として算出した.

\section{（3）処理施設のコストおよひエネルギー消营量}

図一4 (a) で処理施設別のコストをみると, 焼却施設, 堆肥化施設, $\mathrm{RDF}$ 化施設の 3 施設が高い.この内焼却 施設はスケールメリットが大きく, 広域化によって処理 量を増やすことによりコストは低下する. RDF 発電施 設のコストが低いのは，売電による収益をマイナス分と して含めているためで, 図には売電収益を除いた場合の コストも破線で示している. RDF 処理量 $50,000 t$ 年の ときの売却益は 10 千円/ $\mathrm{t}$ となっている. RDF 発電施設 は図ー4 (b)のエネルギー消費量もマイナスであるが, やはり売電によって発電に消費されるエネルギーが削減 されると考えるためである. 処理量 $50,000 t$ 年のとき 3 $\mathrm{Gcal} / \mathrm{t}$ の削減となる. RDF 化施設は逆にエネルギー消 費量が大きいが，ごみの乾燥用に燃料を消費するためで ある. 資源選別施設は回収資源が金属製品之同等の価值 を持ち, 天然資源からの製造エネルギ一を削減できると 考えている. 設定したエネルギ一削減原単位は, スチー ル缶 $2,930 \mathrm{Mcal} / \mathrm{t}$, アルミ缶 $50,200 \mathrm{Mcal} / \mathrm{t}$, びん $1,950 \mathrm{Mcal} / \mathrm{t}, \mathrm{PET}$ ボトル $2,820 \mathrm{Mcal} / \mathrm{t}$ である 8 ). 回収 後のリサイクルプロセスを考虑していないので高目の見 積りだが，今回考慮する全ての処理シナリオに共通して いるので処理シナリオを比較する際には問題とならない. 
なお，図中には 20 万人の場合のごみ処理量を処理方法 別に示した.

\section{（4）処理シナリオことの計算方法}

処理については 1 籄所に集めて処理する場合には広 域ブロック内の合計ごみ処理量を求め, また自治体ごと に個別に処理する場合はそれぞれのごみ処理量を求めて, 図一4に示した関数を用いて計算する. 収集輸送につい ては, 周辺自治体からの輸送距離が異なるので, 自治体 ごとにごみ種別の計算を行う. 以上のごみ種別の処理・ 処分，収集輸送をすべて合計し，広域ブロック全体のコ スト，エネルギー消費量を求めた．収集輸送は家庭ごみ のみを，処理は事業系ごみを含めた全ごみを対象とする.

\section{(5) 自治体配疅のモデル化}

中心都市と周辺自治体の位置関係を，北海道帯広市の 周辺自治体分布（図一 5(a)）を参考にして図ー5(b)の ようにモデル化した. 図中の(1)中心都市人口, (2)周辺自 治体人口, (3)中心都市から周辺自治体までの距離がこの モデルのパラメータである. 図ー5(a)の帯広市周辺の 場合，図一2に示したように人口が少ないと収集車 1 台 でも余裕があり，無馹が大きくなる，そのため以下の計 算では周辺自治体の最小人口を 1 万人とし，中心都市 20 万人に対して人口 1 万人の自治体が中心都市から $5 \mathrm{~km}$, $10 \mathrm{~km}, 15 \mathrm{~km} .$. の位置にある配置を標準広域モデルとして 計算を行った.

\section{5.コスト・エネルギー消貫量の計算結果}

\section{(1)処理シナリオのコスト比較}

表ー 1 に示した処理シナリオのうち，1箇所に集中し て処理する 6 つの集中処理シナリオ（「焼却 $1 」 ， 「$ 「埋 立1」など），および粗大ごみ処理と埋立を個々の自治 体が行う個別埋立シナリオの例として「焼却 $2 」$ ，堆肥 化を個別に行う「堆肥化 1'」のコス卜計算結果を図一 6 (a)に示す. 標準広域モデルに従い横軸は20万人の中 心都市に順次 1 万人の周辺自治体を加えた場合のブロッ ク内合計人口，綐軸は広域ブロック内の全ごみ量 $1 \mathrm{t}$ 当 たり平均コストである. すなわち図の左端は20万人都市 の単独処理, 右端は 20 万人 +1 万人 $\times 20$ 自治体（計 40 万人）の広域処理を示す.

図ー6(a)より集中処理シナリオの平均コストは「埋 立 $1 」<「$ 堆肥化 $1 」<「$ 焼却 $1 」<「($ 堆肥化十焼却) $1 」<\lceil\mathrm{RDF}$ 化 $1 」<\Gamma($ 堆肥化 $+\mathrm{RDF}$ 化 $) 1 」$ 順とな る.「焼却 $1 」 は$ 広域化に伴ってやや平均コストが減少 するが，この理由は図一4(a)に示すように，焼却施設 のスケールメリットによるコストダウンが輸送距離の増 加に伴う収集輸送コストの増加を上回るためである。 （a）北海道帯広市およびその周辺自治体の人口分布 人口[人]

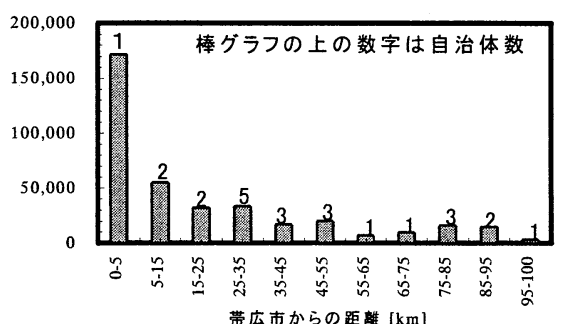

(b) 標準広域モデルの帯市からの距離 $[\mathrm{km}]$

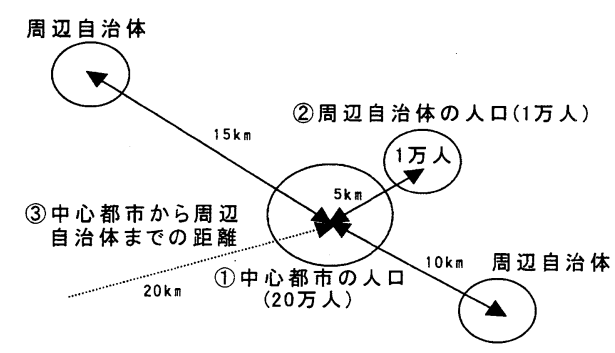

図-5 自治体配置の標準広域モデル

「焼却 $1 」$ のか，全ての施設を 1 箇所に集中する「埋 立 $1 」$, 「堆肥化 $1 」, 「($ 堆肥化+焼却) $1 」$ は広域化 によって平均コストに大きな差がなく, 収集輸送コスト は制約にはならない，一方，「焼却2」の場合は，個々 の自治体に処理量当たり処理コストの高い（図一 4 (a) 参照）小規模の粗大ごみ処理施設や埋立地を設置するた め, 広域化するほど平均コストが增加する. 他の個別埋 立シナリオの結果は省略したが, 集中処理シナリオとの 差は「焼却1」と「焼却2」の差とほぼ同じである.

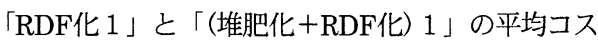
卜は高く, 20 万人 +1 万人 $\times 20$ 自治体のとき「焼却 $1 」$ の約 2 倍になる.これはRDF化施設を各自治体に置く ためである. 堆肥化を各自治体で行う「堆肥化 1 ’」の 場合も, やはり同様の傾向がある.

\section{(2)処理シナリオのコスト内訳}

各処理シナリオごとの処理コストの内訳を詳細に見 るために，図一 7 に中心都市のみ (図一 6 (a)左端，20 万人）と中心都市十周辺自治体（図一6 (a)右端，20万 人+ 1 万人 $\times 20$ 自治体（計 40 万人））のコスト内訳を 示す. 図に示したのは集中処理シナリオであり，焼却と 埋立のみ個別埋立シナリオの場合を示した.

「焼却 $1 」(40$ 万人)の場合, 最も遠い自治体は中心都 市から100km離れているが，前述したように焼却のス ケールメリットが収集輸送コストの増加（中継輸送する ことで低くおさえられる）を上回るため，20万人単独処 理よりコストは低下する。「焼却 $2 」(40$ 万人)は，埋立 


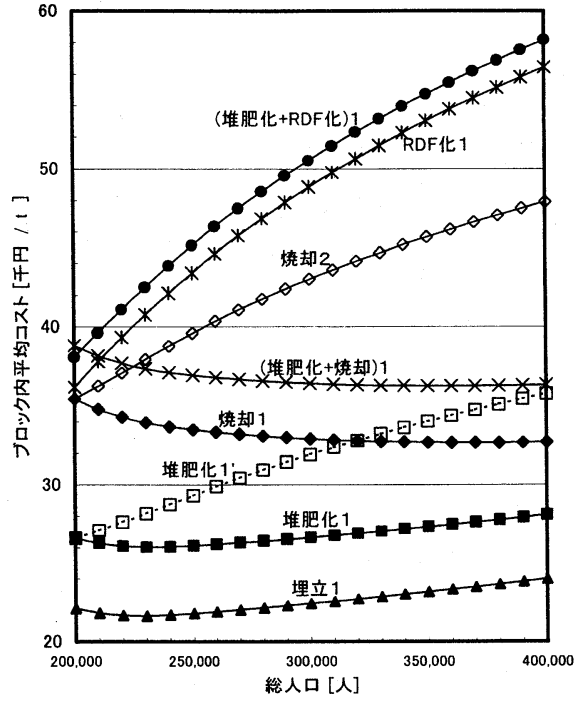

(a)コスト

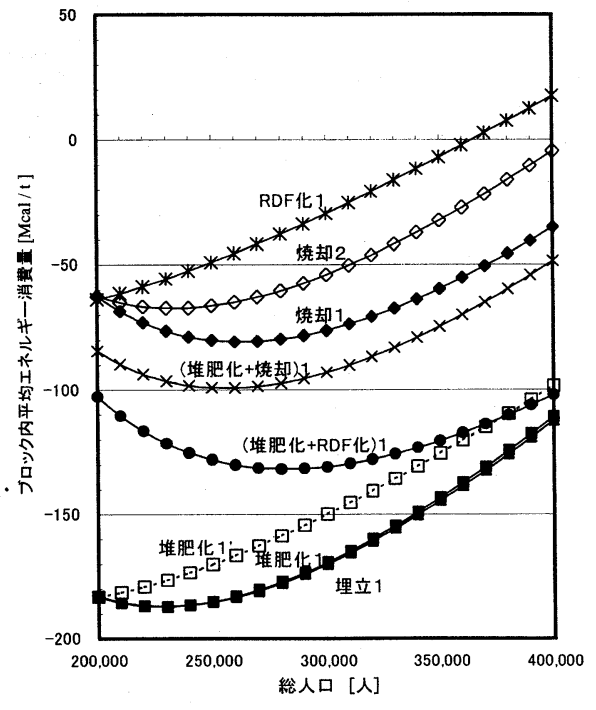

（b）エネルギー消費量

図-6 処理シナリオによるコストおよびエネルギー消費量の違い(標準広域モデルに対して)

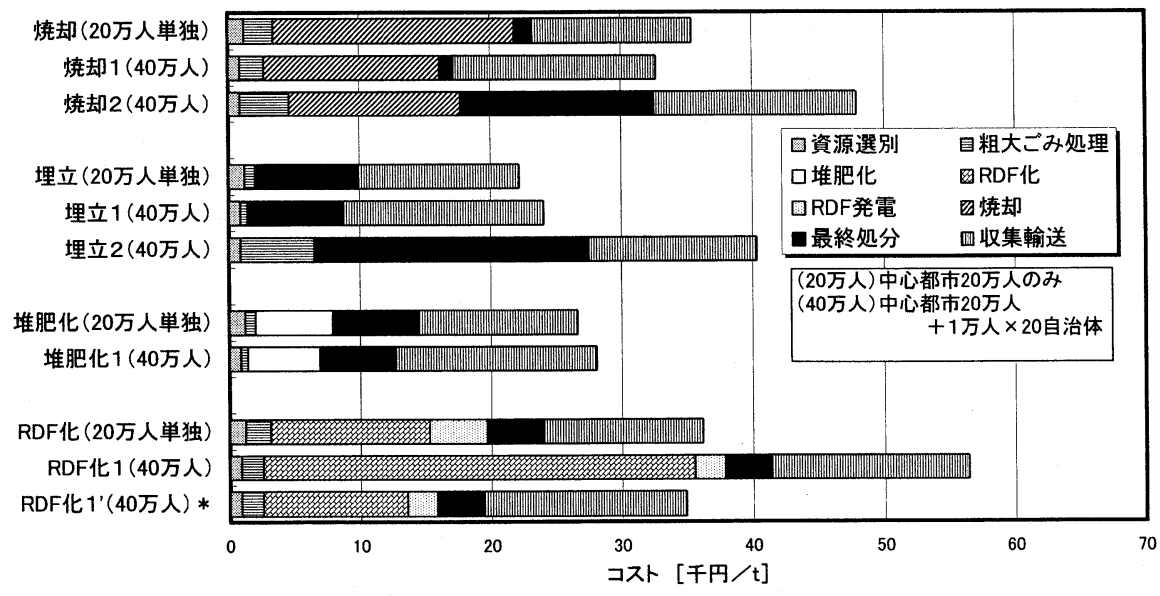

図-7＼cjkstart処理シナリオごとの処理コストの内訳

*RDF1':RDF製造を中心都市に集約

地と粗大ごみ処理施設を各自治体個別に設けるため, 処 理コストの大幅な増加になる.このことは「埋立 $2 」$ (40万人)でも同様である.

「埋立 $1 」, 「$ 堆肥化 $1 」$ のストが広域化によって 増加するのは, スケールメリットが小さく, コストに占 める収集輸送の割合が高いことが原因である。「RDF 化 $1 」$ は個々の自治体がRDF製造を行うとしているの で，広域化による処理コストの増加はきわめて大きい.
図一8にRDF化施設, $\mathrm{RDF}$ 発電施設の処理量当たりコ ストを人口に対して示すが， RDFの製造段階で最低5 万人程度の中間的広域化を行い，10万人以上の規模で発 電するのがよいことがわかる. 周辺自治体 5 万人 $\times 4$ 自治体とすれば「RDF化 $1 」$ の平均コストは中心都市 20万人単独の平均コストとほぼ同じとなる. また, すべ てのごみを中心都市に集めてRDF化を行う場合の平均 コストも，20万人単独処理の場合とほぼ同じとなる（図 
-7の「RDF 1’」シナリオ参照）.

\section{（3）処理シナリオのエネルギー消賞量比校}

図一 $6(\mathrm{~b})$ にはエネルギー消費量の計算結果を示した. 図一4(a)に示したように, RDF発電は規模によらず発 電効率 $30 \%$, 年間負荷率 $86 \%$ として実際の施設より発電 量を多めに計算しているため,「RDF化 $1 」 は R D F$ 発 電によるエネルギー消費量の削減が大きい.しかし, RDF製造のエネルギー消費量によってその効果がうち 消され焼却シナリオよりも劣つている.

エネルギー消費量が最も小さいのは，「埋立 $1 」 ，$

「堆肥化 1 」シナリオである（図一6 (b)では両者はほ とんど重なっている)。

\section{(4) 自治体間のコスト負担格差}

5. (1)では 1 箇所に処理を集中する処理シナリオの場 合, 平均コス卜は広域化によって変化しないことを述べ た. したがって, 輸送が可能な範囲まで広域処理の規模 を拡大することが考えられる. ただし，広域処理の場合， 処理コストは広域ブロックを構成する自治体が平均的に 負担するのに対して，収集輸送コストは各自治体がそれ ぞれ負担する方法が一般的と考えられる.すなおち，両 者の合計が各自治体の負担コストとなる．図一9に「焼 却 $1 」$ シナリオのときの自治体ごとの収集輸送コストを, ブロック内平均処理コストと共に示す. 中心都市から約 $20 \mathrm{~km}$ 程度（直接輸送コスト<中継輸送コストの限界）の 自治体では, 収集輸送コストが中心都市に一番近い自治 体に比べて約 2 倍になり，100k離れると2.5倍程度にま で増加している. つまり, 広域化することによって全体 の平均コストは低減されるものの, 自治体間のコスト負 担格差が問題となる可能性がある.

\section{6. 自治体配置パラメー夕の感度解析}

広域化自治体配置のパラメータとした(1)中心都市人口 規模, (2)周辺自治体人口規模, (3)中心都市加周辺自治 体までの距離のコストに対する影響を, 広域化計画で選 択されることの多い焼却シナリオについて検討した.

図ー10に検討結果を示す. (a)はある中心都市人口に 対し, 人口 1 万人の周辺自治体を 10 自治体（計 10 万人） または20自治体（計20万人）加えて広域化を行った場合 について比較した. 周辺自治体の配置は中心都市から 5 $\mathrm{km}, 10 \mathrm{~km}, 15 \mathrm{~km} .$. とした. 中心都市から「中心都市の み」との差が広域化によるコスト変化を表すが，まず集 中処理シナリオ「焼却 $1 」$ につてみると，中心都市の 人口規模が小さいときほどコスト低減効果は大きい。し かし, 合計人口が 30 万を越えるとあまり変化はない。 個別埋立シナリオ「焼却 2 」の場合は，図一6の説明でも

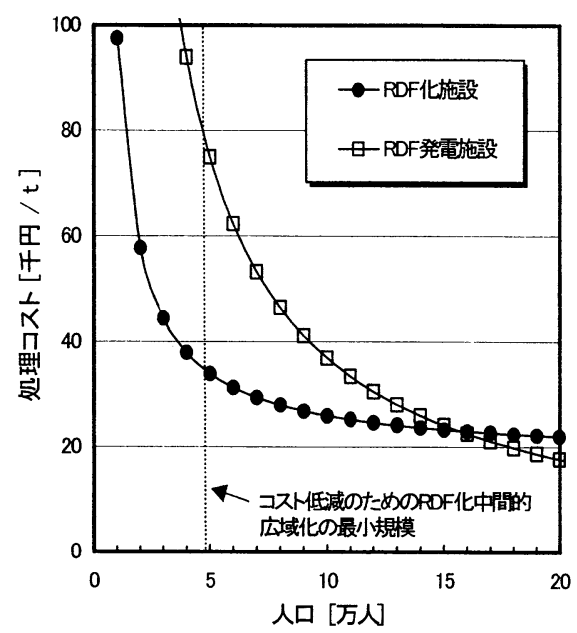

図-8ＲDF化施設およびRDF発電施設の処理コスト

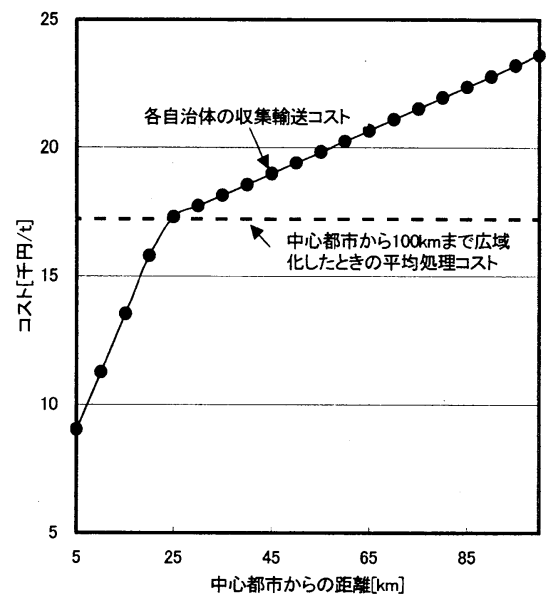

図-9 自治体ごとの収集輸送コストとブロック内平 均処理コスト(「焼却1」シナリオ, 標準広域 モデルに対して)

述べたように広域化するほど逆にコストが増大してしま う.一方，(b)は中心都市に周辺自治体10万人を含めて 広域化を行うとき，周辺自治体の人口分布が異なる場合 の影響を見た. 図中の矢印は，周辺自治体の配置を中心 都市から $10 \mathrm{~km}, 20 \mathrm{~km} ， 30 \mathrm{~km} \ldots$ の距離に 1 万人， $5 \mathrm{~km}$, $10 \mathrm{~km}, 15 \mathrm{~km} \ldots$.. 距離に 1 万人, $5 \mathrm{~km}, 10 \mathrm{~km}, 15 \mathrm{~km} \ldots$ の距離 に2万人とし，後者ほど中心都市に対する広域化の密度 が高い. 中心都市の人口規模とともに平均コストが減少 するのは(a) と同様であり, 広域化の密度が高い（中心 都市の近くに人口の多い自治体がある）ほど平均コスト が小さくなる．また個別埋立シナリオ「焼却2」の場合 


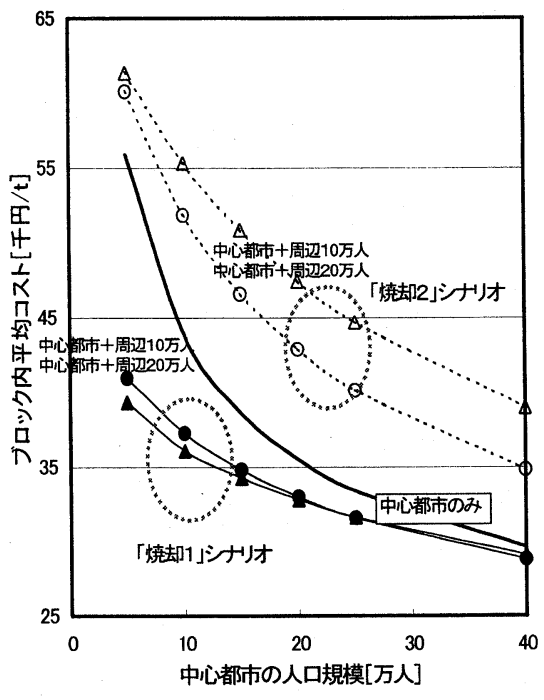

(a) 中心都阨の人口規模と広域化規模による影響

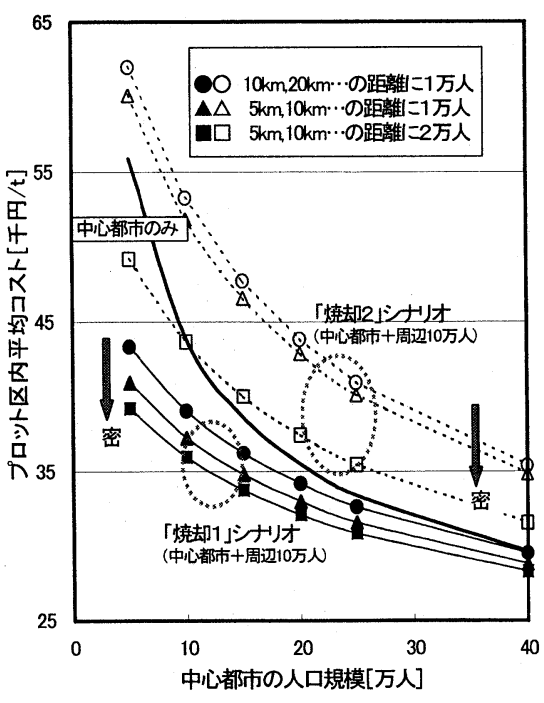

(b) 周辺自治体の配置による影響

図-10 広域化自治体配置パラメー夕の影響(焼却シナリオ)

であっても, 中心都市の人口が10万人以下で広域化密度 の高いときは中心都市単独での平均コストを下回ること がある.

以上のことから, (1)中心都市人口規模, (2)周辺自治体 人口規模，(3)中都市から周辺自治休までの距離の3つ のパラメータでは, (1)が計算に最も影響が大きい因子で あり, また広域化の適正規模を検討するうえで重要であ ることがわかる.

\section{7. おわりに}

本研究では広域化の制約となる収集輸送の条件を検討 し，現実的に考えられるさまざまな処理シナリオに対し 広域化によるコスト，エネルギー消費量の変化を計算し た. 近似式の作成により複雑な処理パターンの計算が可 能であり，ごみ処理量や自治体配置が変化しても容易に 計算できる. また，コスト，エネルギ一消費量の計算結 果は現状を表すのに十分と考えるが，計算に用いた近似 式を修正したとしても容易に再計算が可能であり，各処 理シナリオの比較検討を行ううえで実用的な方法といえ る. 本研究によって明らかとなった点をまとめると以下 のようになる.

1)すべての処理施設を 1 箇所に集中する場合，広域化 の範囲を広げてもコストに大きな変化はなく, 収 集輸送コストは制約とはならない.

2)しかし埋立地, 粗大ごみ処理施設, 堆肥化施設, RDF化施設を自治体が個別に設ける場合，広域化
の範囲を広げるに従ってコストが増加し, 広域化 シナリオとしては望ましくない.

3) RDF化シナリオは, RDF発電のエネルギー削減効 果が極めて大きいものの，製造段階のエネルギー 消費のため，結果として他の処理シナリオよりも エネルギー消費量の点でも有利とはならない.

4) 広域化を行うことの効果は, 中心都市の人口規模が 小さいほどおおきい.

コスト, エネルギー消費量にようて上記のような評価 が得られたが, それ以外に住民の意識や理解などの諸問 題がある. そうした現実上の問題を考慮して，最後にわ が国の廃棄物処理の実状から広域化の実現に関する課題 を以下に示す.

コスト，エネルギー消費量から最も有利な処理シナリ

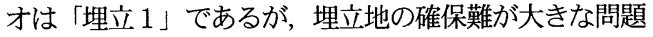
となっているわが国では, 選択される可能性の低いシナ リオといえる. 一方, 粗大ごみ処理施設と埋立地を個別 に設ける「焼却 $2 」 は ，$ 集中処理と較べて広域化による コスト増は大きい. しかし，他の自治体のごみを受け入 れることに対する住民の不満, ごみ処理施設建設に対す る反対を考えると, 現実的に選択される可能性が高いと 考えられ，小規模埋立地の低コスト化が課題である.

またRDF化シナリオは焼却シナリオによる広域化が 困難である場合に選択され，個々の自治体でRDF製造 を行うことが多い. この場合広域化によってRDF製造 に係るコストが増加するため, RDFを製造する段階で ごみを数箇所に集約する等の対策が必要である. また収 
集輸送コストも増加するが, $\mathrm{RDF}$ 発電の建設・運営を 別途設立した第三セクター（都道府県，関係自治体等の 出資による）が行う新しい方式(13),14)が始められており， 第三セクター側が必要に応じてRDFの収集輸送を行う などの自治体の負担軽減対策が必要である.

\section{文献}

1）秦 泰之: ごみ処理の広域化について, 都市清掃, 第 51 巻 第 224 号, pp. 222-225, 1998.

2）環境大臣官房廃棄物・リサイクル対策部廃棄物対課：「廃棄 物の減量その他その適正な処理に関する施策の総合的かつ 計画的な推進を図るための基本的な指針」について一国の 基本方針について一, 都市清掃, 第 54 巻, 第 243 号, pp. 415-418, 2001.

3）仁井本貴庸, 岩㴊善美, 東野 達, 笠原三紀夫 : ごみ処 理・処分の広域化に関するエネルギー及び環境への影響, 第11回廃棄物学会研究発表会講演論文集, pp. 171-173, 2000.

4) 中野加都子, 和田安彦: 広域化が環境に与える影響の評価, 環境管理, Vol.38, No.4, pp.324-331, 2002.

5）谷口正修, 中野加都子, 三浦浩之, 和田安彦: ごみ広域処 理の環境負荷の低減に関する研究, 第11回廃棄物学会研究 発表会講演論文集, pp. 168-170, 2000.

6) 清水 剛, 内海秀樹, 寺島 泰: ごみ処理の広域化の環 境・経済面からの評価に関する研究, 環境システム研究, Vol.27, pp. 429-434, 1999.
7）有機質資源化推進会議 : 有機廃棄物資源化大事典, 農山村 文化協会, pp. 51-64, 2000.

8）松藤敏彦, 田中信壽 : 一般廃棄物処理システムのコスト・ エネルギー消費量・二酸化炭素発生量評価手法の提案, 土 木学会論文集, No.678/VII-19, pp.49-60, 2001.

9）北海道大学工学研究科廃棄物処分工学分野 : 都市ごみの総 合管理を支援する評価計算システムの開発に関する研究, 1998.

10）(財）日本環境衛生センター「一般発裹物処理事業実態調 査 (平成 7 年度) CD-ROM」, 2000 .

11）井村秀文, 銭谷賢治, 中嶋芳紀, 森下兼年, 池田秀昭: 下 水道システムのライフサイクルアセスメント : LCE及び LC-C02による評価, 土木学会論文集, No. 552/VII-1, pp. 75-84, 1996.

12）北海道企業局: 高効率廃棄物発電 (一廃等RDF利用) 事業化 及びRDF製造から発電までを一貫して行う事業(公設民営 方式)の可能性調査報告書, pp. 59-95, 1998.

13）広島県 : 循環型経済拠点構想一びんごエコタウン構想一, pp. 25-29, 2000.

14）大牟田市ホームページ : 広域的なダイオキシン対策を目指 すRD F発電計画

(http://www. ci ty. omuta. fukuoka.jp/chiiki/kankyou/suisin)

\section{COMPARATIVE STUDY ON REGIONAL SOLID WASTE MANAGEMENT SYSTEM IN TERMS OF COST AND ENERGY CONSUMPTION}

\section{Hiroshi HABARA, Toshihiko MATSUTO, Nobutoshi TANAKA and Machiko INOUE}

\footnotetext{
Using a computer model, studies were conducted on the regional solid waste management system, in which collected wastes of several member municipalities are transferred to a central treatment/disposal facility. First, the waste collection and transport activities, which are considered constraints for an extending service area, were scrutinized. Then, with a model made up of location, population, etc. of each member municipality, the cost and the energy consumption were calculated for a typical solid waste management scenario. Each scenario is composed of the activities such as incineration, landfill, composting, RDF, etc. as principal treatment processes, and modified cases in which each municipality has a landfill were also included. Finally, the sensitivity analysis for location parameters was carried out.
} 